\title{
Identification of Novel Proteins Interacting with Vascular Endothelial Growth Inhibitor 174 in Renal Cell Carcinoma
}

\author{
QIANG ZHAO ${ }^{1 *}$, DUOER KUN ${ }^{2 *}$, BAOAN HONG $^{3 *}$, XIAOHU DENG $^{4}$, SHENG GUO $^{5}$, XINGXING TANG $^{1}$, \\ YONG YANG ${ }^{1}, \mathrm{KAN}_{\mathrm{GONG}}{ }^{3}$, QING $\mathrm{LI}^{6}$, LIN YE$^{7}$, WEN G. JIANG ${ }^{7}$ and NING ZHANG ${ }^{1}$ \\ ${ }^{1}$ Beijing Institute for Cancer Research, Department of Urology, Beijing Cancer Hospital, Beijing, P.R. China; \\ ${ }^{2}$ Department of Urology, Central Hospital of HaMi Region in XinJiang Province, Hami, P.R. China; \\ ${ }^{3}$ Department of Urology, Peking University First Hospital, Institute of Urology, \\ Peking University, Beijing, P.R. China; \\ ${ }^{4}$ Department of Urology, People's Hospital of Kelamayi in XinJiang Province, Kelamayi, P.R. China; \\ ${ }^{5}$ Division of Translational Oncology, Crown Bioscience, Taicang, P.R. China; \\ ${ }^{6}$ Centre for Cellular \& Structural Biology, School of Pharmaceutical Sciences, \\ Sun Yat-Sen University, Guangzhou, P.R. China; \\ ${ }^{7}$ Metastasis \& Angiogenesis Research Group, Cardiff University School of Medicine, Cardiff, U.K.
}

\begin{abstract}
Background/Aim: Vascular endothelial growth inhibitor (VEGI) is a multipotential cytokine that plays a role in regulating immunity, anti-angiogenesis, and inhibiting tumor growth. However, the proteins that interact with it are still unknown. In the present study, we examined the proteins that interact with VEGII74 and their expression in renal cell carcinoma (RCC). Materials and Methods: The proteins that interact with VEGII74 were identified using western blot, pull-down assay, and mass spectrometry. The expressions of VEGI174 and the interacting proteins were examined in RCC and were compared to normal renal tissues using immunohistochemical staining and RNA-seq respectively. Results: The results of the mass spectrometric analysis showed that ACLY, ENOI, ZIK1, AKRIC3, and $M Y C$ may interact with VEGII74. When compared to the TCGA database, the expression level of VEGII74 in RCC was lower than that in normal kidney using RNAseq
\end{abstract}

\footnotetext{
*These Authors contributed equally to this study.

Correspondence to: Prof. Wen G. Jiang, Metastasis and Angiogenesis Research Group, Department of Surgery, Cardiff University School of Medicine, Heath Park, Cardiff, CF14 4XN, U.K. Tel: +44 02920742895, Fax: +44 2920742896, e-mail: jiangw@cf.ac.uk and Dr. Ning Zhang, Beijing Institute for Cancer Research, Beijing Cancer Hospital, 52 Fucheng Road, Haidian District, Beijing, 100142, P.R. China. Tel: +86 1088196959, Fax: +861088196064, e-mail: niru7429@126.com
}

Key Words: Vascular endothelial growth inhibitor (VEGI), renal cell carcinoma, pull-down assay, mass spectrometric, AKR1C3. $(p<0.001)$. The expression levels of ACLY, ENO1, ZIKI, $A K R 1 C 3$ and MYC in RCC were higher than those in normal kidney $(p<0.05$, all of above factors $)$. Moreover, immunochemical staining results also showed that the expression levels of AKRIC3 in RCC were significantly higher those that in normal kidney $(p<0.001)$ and was also positively correlated with higher RCC stage and grade. Conclusion: Taken together, our findings showed that VEGI174 may interact with ACLY, ENO1, ZIK1, AKRIC3, and MYC. The expression of ACLY, ENO1, AKRIC3 and $M Y C$ is increased in RCC. AKRIC 3 was a new factor that may correlate with the progression of RCC. The results indicated that VEGII74 has more functions than we currently know in the development and progression of RCC.

Vascular endothelial growth inhibitor, VEGI (also known as tumor necrosis factor superfamily member 15 (TNFSF15) and TNF ligand related molecule 1 (TL1)), is an antiangiogenic cytokine that belongs to the TNFSF family of proteins (1-3). Three isoforms of VEGI (VEGI 174, VEGI192, VEGI 251) have been reported, all of them share a common region of $453 \mathrm{bp}$ that encodes a domain of 151 amino acids at the $\mathrm{C}$-terminus but they differ in their $\mathrm{N}$ terminal regions (4-6). The biological activity of VEGI mainly depends on the solubilised extracellular domain of the three isoforms. VEGI is a multipotential cytokine that plays a role in inflammation, septic shock, fever, and growth modulation through inducing apoptosis, regulating immunity and anti-angiogenesis. Thus, VEGI may play a role as a target for anti-tumor growth via its inhibitory role on antiangiogenesis and regulating immunity (7). A great amount of 
evidence has also shown that overexpression of VEGI could inhibit tumor neovascularisation and progression in cellular and animal models $(2,8)$.

First, VEGI is able to inhibit the growth of various human tumor cell lines including human histiocytic lymphoma (U-937), human breast carcinoma (MCF-7), human epithelial carcinoma (HeLa) and human myeloid lymphoma ML-1a (9). Second, VEGI is shown to inhibit tumor growth in vivo. It also suppresses the growth of colon carcinoma cells (murine colon cancer cells, MC-38) both in vitro and in vivo $(2,3,10)$. Systemic administration of VEGI 192 remarkably inhibited tumor growth and increased survival time of treated animals in a Lewis lung carcinoma (LLC) murine tumor model (11). In 2006, Parr et al. reported that patients with breast tumors expressing reduced levels of VEGI had a higher local recurrence, shorter survival time and an overall poorer prognosis than patients expressing higher levels of VEGI (7). In 2013, Jia et al. reported that the expression level of VEGI was significantly lower in pituitary tumors which invaded the sellafloor, and with suprasellar extension than that of non-invasive tumors (12). They suggested that VEGI was an independent indicator for invasion in human pituitary adenomas. Our previous studies demonstrated that VEGI expression could significantly reduce motility and adhesion of renal, prostate and bladder cancer cells $(13,14)$. VEGI expression was decreased in renal cell carcinoma (RCC), particularly in high-grade tumors. Furthermore, full length VEGI174 could suppress the growth of RCC in vivo (15-17). In addition, VEGI is also a T-cell co-stimulator and can directly stimulate dendritic cell maturation $(8,18)$. However, it is still unclear whether activation of tumor specific or non-specific B or $\mathrm{T}$ lymphocytes may operate in soluble VEGI-mediated tumor suppression.

It is well known that tumor angiogenesis and immunity are closely related with RCC progression. Our studies showed that VEGI174 might be a putative tumor suppressor and a potential therapeutic target for RCC. However, it is unclear whether VEGI174 acts solely or in collaboration with other proteins as part of a protein complex. In this study, the proteins that interact with VEGI174 were identified by immunoprecipitation and mass spectrometry. The expression of VEGI174 and associated proteins was also examined in RCC tissues using the RNA-seq method.

\section{Materials and Methods}

Cell lines. All cell lines used in this study were purchased from the American Type Culture Collection (ATCC, Rockville, MD, USA). Human emborynic kidney 293 T cell line (HEK293T) and Chinese hamster ovarian line (CHO) were used in this study. Cells were routinely cultured with Dubecco's modified Eagle's medium (DMEM) supplemented with $10 \%$ fetal calf serum, penicillin and streptomycin (Gibco BRC, Paisley, UK).
Antibodies. Antibodies were purchased from the following sources: The monoclonal anti-Flag M2 Tag was purchased from SigmaAldrich Co. LLC. (F1804, Sigma-Aldrich Co. LLC., St. Louis, USA). The monoclonal Rabbit anti-human-ACLY (ATP citrate lyase) and anti-human-ENO1 (Enolase 1) antibodies were purchased from Abcam Inc. (EP704Y and EPR10863, Abcam Inc., Cambridge Science Park, UK). The monoclonal mouse anti-human-VEGI174 antibody was purchased from LSBio Inc. (LS-C76815, LSBio Inc., Seattle, WA, USA). Monoclonal mouse anti-human-AKR1C3 (Aldo-ketoreductase family 1 member C3) antibody was kindly supplied by Professor Qing from the Centre for Cellular \& Structural biology, School of Pharmaceutical Sciences, Sun Yat-Sen University, Guangzhou, P.R. China.

Human RCC specimens. A total of 16 pairs of renal cell carcinoma and normal renal tissue samples were snap-frozen in liquid nitrogen immediately after radical nephrectomy. The pathologist verified normal and cancer specimens. All protocols were reviewed and approved by local ethics committee and all patients were given written informed consent. Nine patients were in clinical stage T1 and 7 patients were in T3. In addition, 1 patient was in Fuhrman Grade 1, 8 patients were in Fuhrman Grade 2, 6 patients were in Fuhrman Grade 3, and 1 patient was in Fuhrman Grade 4.

RNA isolation and reverse transcription PCR. RNA was isolated using Total RNA Isolation reagent (ABgene, Epsom, UK). First strand cDNA was synthesized from $0.5 \mu \mathrm{g}$ RNA using a reverse transcription kit (Sigma, Poole, Dorset, UK). The quality of cDNA was verified through amplification and detection of the GAPDH housekeeping gene. Forward and reverse primers of VEGI (Table I) were designed based on human VEGI sequence (GeneBank accession no. BD131562). PCR was performed in a GeneAmp PCR system 2400 thermocycler (Perkin-Elmer, Norwalk, CT, USA). Conditions for PCR were $40 \mathrm{sec}$ at $94^{\circ} \mathrm{C}, 60 \mathrm{sec}$ at $55^{\circ} \mathrm{C}, 60 \mathrm{sec}$ at $72^{\circ} \mathrm{C}(35$ cycles). PCR products were separated on a $1.4 \%$ agarose gel.

Establishment of Stable Transfectants. CHO and HEK293T cells were transfected with $3 \mu \mathrm{g}$ of full-length human VEGI174 coding sequence (Table I) cloned into pcDNA3.1+ expression vector (Invitrogen Inc., Paisley, UK) by Lipofectamine 2000. CHO-stable transfectants of full-length human VEGI174 coding sequence were selected for 2 weeks by $2 \mathrm{mg} / \mathrm{ml}$ G418 (Invitrogen Inc., Paisley, UK) before being subjected to cloning by limiting dilution.

Western-blotting analysis. CHO or HEK293T cells $\left(1 \times 10^{6}\right)$ at $48 \mathrm{~h}$ after transient transfection with $3 \mu \mathrm{g}$ of full length VEGI174 using Lipofectamine 2000 (Invitrogen Inc., Paisley, UK), or the same number of the CHO stable cloned VEGI174 were lysed in $200 \mu \mathrm{l}$ of lysis buffer $(50 \mathrm{~mm} \mathrm{NaCl}, 20 \mathrm{~mm}$ Tris, $\mathrm{pH} \mathrm{7.6,} \mathrm{1 \%} \mathrm{Nonidet} \mathrm{P-}$ $40,1 \times$ protease inhibitor mixture) for $1 \mathrm{~h}$. The lysates were cleared by centrifugation at $16,000 \times g$ at $4^{\circ} \mathrm{C}$ for $10 \mathrm{~min}$. Crude protein concentration was measured by DC Protein Assay kit (Bio-Rad) and ELx800 spectrophotometer (Bio-Tek ${ }^{\mathrm{TM}}$ ). Two hundred $\mu \mathrm{g}$ of total protein of each sample was transferred to a new microcentrifuge tube, and immunoprecipitation was performed with $2 \mu \mathrm{g}$ of the indicated antibodies and $50 \mu \mathrm{l}$ of protein-G slurry for overnight incubation. Ten $\mu$ l of the precipitated materials were subjected to western blot analysis with the indicated antibodies. Primary antibody was incubated with the membrane in the dilution recommended by the manufacturer. The bound primary antibody 
Table I. PCR primer sequences.

\begin{tabular}{lll}
\hline Primer & Forward & Reverse \\
\hline$h G A P D H$ & 5'-AGCTTGTCATCAATGGAAAT & 5'-CTTCACCACCTTCTTGATGT \\
$V E G I$ & 5'-ATGAGACGCTTTTTAAGCAA & 5'-CTATAGTAAGAAGGCTCCAAAG \\
$V E G I$ (expression) & 5'-ATGAGACGCTTTTTAAGCAA & 5'-CTATAGTAAGAAGGCTCCAAAGA \\
\hline
\end{tabular}

was visualized with HRP-conjugated secondary antibody using Supersignal $^{\mathrm{TM}}$ West Dura system (Pierce Biotechnology, Inc., Rockford, IL, USA) and photographed using an UVITech imager (UVITech, Inc., Cambridge, UK).

Affinity purification of flag-tagged VEGI174 and mass spectrometry. Flag tagged VEGI174 was stably expressed in HEK293T cells. Two liters of cell culture was harvested and treated with or without 20 Gy IR. Four hours after IR treatment, cells were lysed with $40 \mathrm{ml}$ NETN buffer on ice for $10 \mathrm{~min}$. Cell lysates were centrifuged at $12,000 \mathrm{~g}$ at $4^{\circ} \mathrm{C}$ for $20 \mathrm{~min}$. Soluble fraction was collected and insoluble fraction was washed three times with PBS and then treated with 50 units of micrococcal nuclease on ice for $1 \mathrm{~h}$ and centrifuged at $12,000 \mathrm{~g}$ at $4^{\circ} \mathrm{C}$ for $20 \mathrm{~min}$. The supernatant was the chromatin fraction combined with the NETN soluble faction. Cell lysates were incubated with $500 \mu \mathrm{l}$ streptavidin conjugated beads (Amersham, Tokyo, Japan) at $4^{\circ} \mathrm{C}$ for $2 \mathrm{~h}$. The beads were washed three times with NETN buffer, and then bead-bound proteins were eluted with $1 \mathrm{ml}$ PBS containing $2 \mathrm{mM}$ biotin (Sigma, Poole, Dorset, UK). The eluted supernatant was incubated with $50 \mu \mathrm{S}$ beads (Novagen, California, US) at $4^{\circ} \mathrm{C}$ for $2 \mathrm{~h}$. The beads were washed three times with NETN buffer and subjected to sodium dodecyl sulfatepolyacrylamide gel electrophoresis. The gels were digested, and the peptides were analyzed by liquid chromatography-tandem mass spectrometry.

Mass Spectrometric Analysis. MALDI quadrupole time-of-flight mass spectrometry (Applied Biosystems/MDS Sciex QSTAR Pulsar) was used to identify VEGI174 associated proteins by peptide mass fingerprinting and the peptide sequence information was obtained by MS/MS analysis. The peptide masses and the amino acid sequences identified from the peptide fragmentation data were subjected to MASCOT and PROSPECTOR searching engines.

Genomic analysis of RCC tissues. For transcriptome sequencing (RNA-seq) of renal cell carcinoma tumor tissues, snap frozen samples were used to extract RNA. Its purity and integrity were checked by Agilent Bioanalyzer prior to RNA sequencing. Only RNA samples with RIN $>7$ and 28 S/18S $>1$ were proceeded for library construction and sequencing. The sequencing was performed at PE125 on an Illumina HiSeq2500 platform by certified Illumina service providers. Transcript expression was estimated by MMSEQ (19) and represented by $\log _{2}$ (FPKM).

Immunohistochemical staining of renal specimens. Frozen specimens of renal cell carcinoma $(n=16)$ and normal renal tissue $(n=16)$ were cut at a thickness of $6 \mu \mathrm{m}$ using a cryostat (Leica CM 1900, Leica Microsystems UK Ltd., Buckinghamshire, UK). The nature of the samples was independently verified by two pathologists. After fixation, the sections were blocked with horse serum and probed with or without VEGI174, ACLY, ENO1 or AKR1C3 antibodies for $1 \mathrm{~h}$. The secondary biotinylated antibody and the avidin-biotin complex were subsequently applied to detect VEGI expression in accordance with the Vectastain Universal Elite ABC kit protocol (Vector Laboratories, Peterborough, UK). After developing color with DAB, the sections were counterstained with Gill's hematoxylin. Staining was independently assessed by the authors.

Statistical analysis. Statistical analysis was performed using the SPSS 19.0 software. The two sample $t$-test was used for normally distributed data. Fisher's exact test was used for analyzing immunohistochemical staining in renal cancer tissues. Differences were considered to be statistically significant at $p<0.05$.

\section{Results}

Genetic manipulation of VEGI levels in HEK293T and CHO cell lines. HEK293T and CHO cells were transfected with a VEGI expression construct to create sublines showing enhanced levels of VEGI expression. VEGI174 was transfected into $\mathrm{CHO}$ as a positive control of HEK293T. As shown by RT-PCR analysis, VEGI mRNA expression was significantly increased in HEK293 $\mathrm{T}^{\mathrm{VEGI}}$ and $\mathrm{CHO}^{\mathrm{VEGI}}$ cells compared with wild-type (Figure 1A). Western blot demonstrated that VEGI protein expression was significantly increased in HEK293T $\mathrm{T}^{\mathrm{VEGI}}$ and $\mathrm{CHO}{ }^{\text {VEGI }}$ cells compared to wild-type cells (Figure 1B).

Results of mass spectrometric Analysis. VEGI174 was purified using ANTI-FLAG affinity resin. Protein samples were eluted by gradient FLAG peptide from 300 to $1,000 \mu \mathrm{g} / \mathrm{ml}$ (Figure 2 ). The gels were digested, and the peptides were analyzed by liquid chromatography-tandem mass spectrometry. The common non-specific associated proteins, including acetyl coenzyme A carboxylase 1, pyruvate carboxylase, methylcrotonoyl coenzyme A carboxylase subunit alpha, heat shock protein superfamily and myosins, are not listed in the mass spectrometry results shown in Table II. There were five proteins that may interact with VEGI174.

RNAseq analysis of renal cell carcinoma tissues. The expression of genes was examined in 16 RCC tissues by RNAseq. In the present study, we analysed more than five genes which may interact with VEGI174. Comparing against 
A

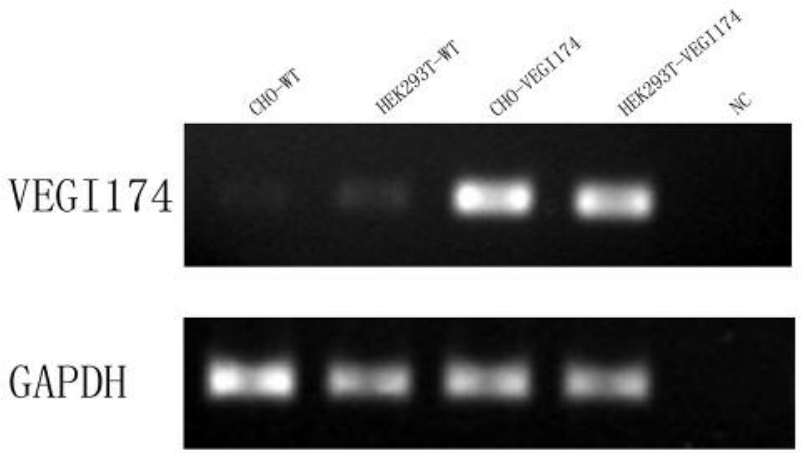

B

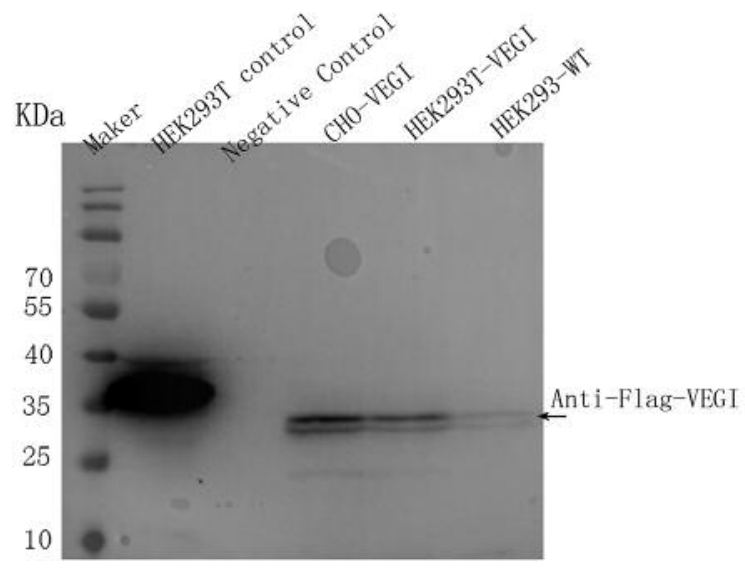

Figure 1. Confirmation of manipulation of VEGI174 expression in HEK293T and CHO cells. A: Verification of forced expression of the VEGI174 transcript in HEK293T and CHO cells. VEGI174 mRNA expression in the HEK293T and CHO cells was higher than that in wild-type cells. B: Forced expression of VEGI174 at the protein level using western blot analysis of HEK293T and CHO cells. VEGII74 protein level was increased in HEK293T and CHO cells compared with that of wild-type cells.

Table II. Five proteins that may interact with VEGI174.

\begin{tabular}{lccc}
\hline Mass & Protein Name & NBCI ID (Homo sapiens) & UnitProt database \\
\hline 121342 & ATP citrate lyase (ACLY) & Gene ID: 47 & http://www.uniprot.org/uniprot/P53396 \\
97665 & Aldo-ketoreductase family 1 member C3(AKR1C3) & Gene ID: 8644 & http://www.uniprot.org/taxonomy/9606 \\
54721 & zinc finger protein interacting with K protein 1 (ZIK1) & Gene ID: 284307 & http://www.uniprot.org/uniprot/Q3SY52 \\
47111 & enolase 1 variant (ENO1) & Gene ID: 284307 & http://www.uniprot.org/uniprot/P06733 \\
36532 & C-myc proto-oncogene, MYC & Gene ID: 4609 & http://www.uniprot.org/uniprot/P01106 \\
\hline
\end{tabular}

the TCGA database, the expression level of VEGI174 $(-0.4626)$ in RCC was lower than that in normal kidney $(p=0.006)$. The expression levels of ACLY (6.6992), AKR1C3 (6.3558), ENO1(4.330), ZIK1(0.5451) and MYC (5.2869) in RCC were higher than that in normal kidney ( $p$-values were $0.001,0.0045,0.001,0.002$, and 0.001 , respectively).

In stage $\mathrm{T} 1$ group, the expression level of AKR1C3 was lower than that of stage T3 group, $p=0.003$. The expression level of ENO1 in stage T1 was higher than that of stage 3 group, $p=0.029$. However, there were no differences in the expression levels of VEGI, ACLY, MYC and ZIK1, $p=0.114$, $0.502,0.826$, and 0.822 , respectively.

In addition, Fuhrman Grade 1 group and Fuhrman Grade 2 group were merged into a low-grade group. Fuhrman Grade 3 group and Fuhrman Grade 4 group were merged into a high-grade group. The low-grade group expression level of AKR1C3 was lower than that of the high-grade group, $p=0.001$. The low-grade group expression level of ENO1 was higher than that of the high-grade group, $p=0.020$.
However, there were no differences in the expression levels of VEGI, ACLY, MYC and ZIK1, $p=0.261,0.578,0.936$, and 0.989 , respectively.

Detection of VEGI174, ACLY, ENOI and AKRIC3 protein by immunohistochemistry. There are many researches on MYC and ZIK1, therefore we did not detect them in this study. In immunohistochemical staining, VEGI174 was seen in the cytoplasmic area of normal renal tubular epithelia cells, but the staining was decreased or absent in RCC cells, particularly in specimens with high-grade tissues (Figure $3 \mathrm{~A})$. The positive staining of normal tissues $(87.5 \%, 14 / 16)$ was significantly higher than that of RCC tissues $(31.25 \%$, 5/16), $p=0.006$.

ACLY was seen in the cytoplasm of normal renal tubular epithelia cells. The staining was seen in the cell membrane and cytoplasm of RCC tissues (Figure 3B). However, there was no significant difference of ACLY expression between normal renal and RCC tissues, $p=0.342$. 


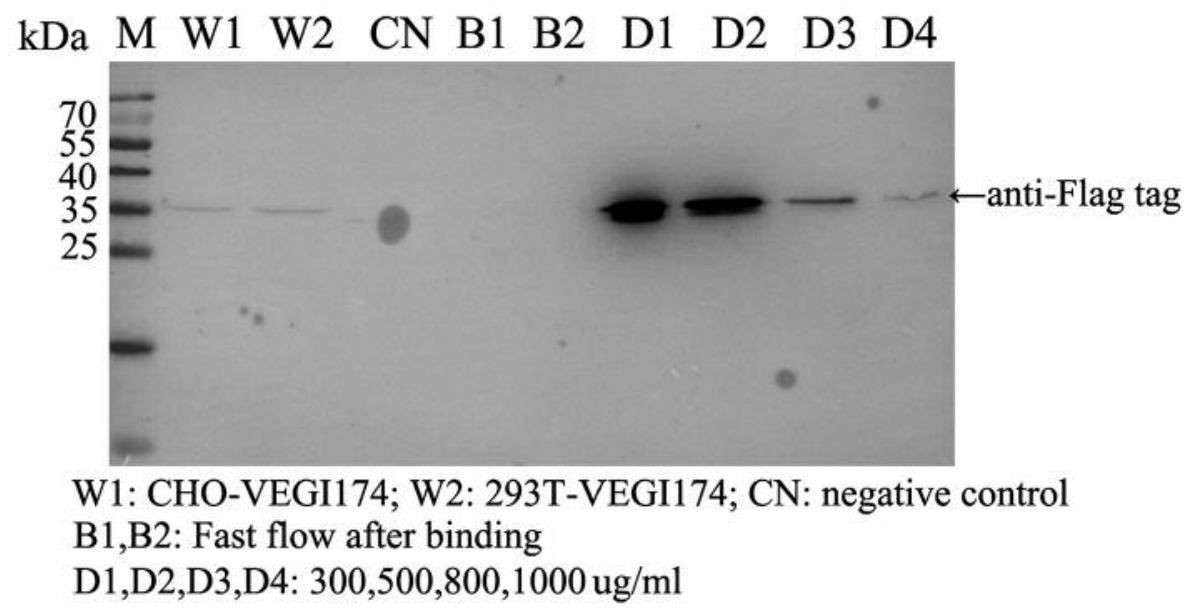

Figure 2. Co-immunoprecipitation of VEGII74 with its associated proteins. Co-immunoprecipitation of VEGI174 was performed by using anti-flag monoclonal antibody conjugated beads from CHO or HEK293T cells stably transfected with flag-labeled VEGI174 expression construct. The eluent was immunoblotted by anti-flag monoclonal antibody.

ENO1 was seen in the cytoplasmic and nucleus area of normal renal tubular epithelia cells. The staining was also seen in the cytoplasmic and nucleus area of RCC tissues (Figure $3 \mathrm{C})$. However, there was no significant difference of ENO1 expression between normal renal and RCC tissues, $p=0.117$.

AKR1C3 was seen in the cytoplasm of normal renal tubular epithelia cells, but the staining was increased in the cytoplasmic and nucleus area of RCC tissues (Figure 3D). The positive staining of normal tissues $(25 \%, 4 / 16)$ was significantly lower than that of RCC tissues $(81.25 \%, 13 / 16)$, $p=0.002$. Moreover, the higher expression level of AKR1C3 was seen in higher stage and grade of RCC.

\section{Discussion}

RCC is a wide-spread oncourological disease with a tendency towards morbidity progression. At the time of RCC diagnosis, metastatic lesions are present in $20-30 \%$ of patients $(20,21)$. Also, in $20-30 \%$ of patients with preoperative absence of metastases, after nephrectomies metastatic lesions appear or local recurrence of disease take places $(22,23)$. Surgical treatment of kidney tumors is the only effective treatment modality. Until the 21 st century, the efficacy of drug therapy for disseminated RCC (interferon$\alpha$, interleukins, hormonal therapy and chemotherapy) was insignificant or absent, and the median overall survival (OS) in metastatic disease rarely exceeded 8 months (24). It was only in the recent decade, after deeper understanding of the peculiarities of initiation and development of tumor progression in RCC, that it became possible to approve more efficacious drugs targeting key molecules involved in the RCC carcinogenesis.
VEGI is a multipotential cytokine that plays a role in regulating immunity, anti-angiogenesis, and inhibiting tumor growth $(16,25)$. Studies have shown that overexpression of VEGI could inhibit tumor neovascularization and progression in cellular and animal models. Our pre-study also showed the VEGI174 inhibitory effect on cellular motility, adhesion, vascular endothelial tube formation and tumor growth in vivo (15). It was suggested that VEGI174 functions mainly through inhibition of angiogenesis and is a negative regulator of aggressiveness during the development and progression of RCC (17).

A few mechanisms underlying the inhibitory effect of VEGI on angiogenesis were revealed. First, VEGI prevents $\mathrm{G}_{0} / \mathrm{G}_{1}$ endothelial cells from re-entering the cell cycle in response to growth stimuli. Second, there are two members of the TNF receptor superfamily which VEGI interacts with, namely death receptor 3 (DR3) and decoy receptor 3 (DcR3). DR3 is the functional receptor of VEGI251. It contains a death domain in its cytoplasmic tail and induces apoptosis in death receptor-3-expressing cell lines, such as in human umbilical vein endothelial cells (HUVECs). On the contrary, previous studies indicated that DcR3 is overexpressed in malignant tumors arising from the oesophagus, stomach, glioma, lung, colon and rectum (10, 18, 26-28). DcR3 enhances angiogenesis by blocking the autocrine-angiostatic function of VEGI in human umbilical vein endothelium (18). Meanwhile, anti-VEGI and -DR3 antibodies lead to increases of both cell proliferation and motility, and an induction of the formation of tube network (29). The angiogenic effect of VEGI antibody and DR3 antibody is similar to that induced by DcR3. Furthermore, VEGI induces apoptosis in actively proliferating cells, via activation of the stress protein kinases, 

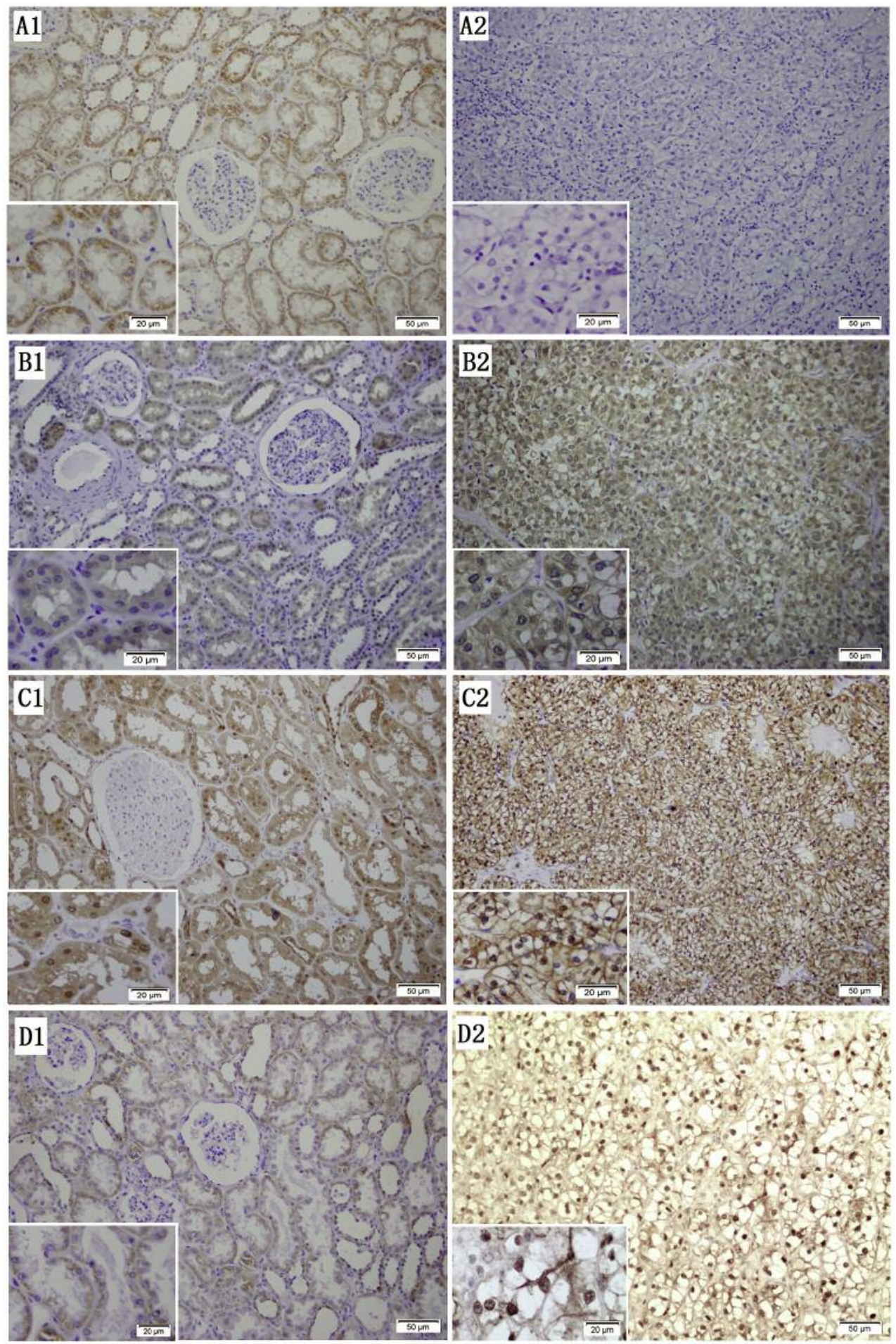

Figure 3. Immunohistochemical staining of human renal specimens. A1, B1, C1 and D1 were normal renal tissues. The VEGI, ACLY, Eno1 and AKRIC3 protein was found to be stained in the cytoplasmic area of normal renal tubular epithelia cells. ENO1 was also seen in some nucleus areas of normal renal tubular epithelia cells. A2, B2,C2 and D2 were renal cell carcinoma tissue. A2, the staining of VEGI174 was decreased or absent in RCC cells, particularly in specimens with high-grade tissue. The positive staining of normal tissue was significantly higher than that of RCC tissues, $p=0.006 . B 2$, the staining of ACLY was seen in cell membrane and cytoplasmic in RCC tissues. C2, the staining of ENO1 was seen in cytoplasmic and nucleus area of RCC tissues. There was no significant difference of ACLY and ENO1 expression between normal renal and RCC tissues ( $p=0.342, p=0.117$, respectively). D2, the staining of AKR1C3 was increasing in cytoplasmic and nucleus area of RCC tissues. The positive staining of normal tissue was significantly lower than that of RCC tissues, $p=0.002$. 
SAPK/JNK and p38 MAPK (SAPK, stress-activated protein kinase, JNK, c-Jun N-terminal protein kinase, p38 MAPK, p38 mitogenactivated protein kinase), and the caspases, mainly caspase-3-like protease. Additionally, VEGI-induced apoptosis is attenuated by a caspase inhibitor.

However, it is still unclear whether VEGI174 acts solely or in collaboration with binding proteins in the form of a protein complex. In this study, we showed that there were five proteins that may interact with VEGI174. For MYC, it is well known that its pathway is activated in most cases of human RCC. The $M Y C$ oncogene contributes to tumorigenesis of many types of cancer through various mechanisms (30-33), including the regulation of proliferation and growth, protein and ribosomal biogenesis, changes in metabolism, lipid synthesis, and induction of angiogenesis (34-37). For Zinc finger protein interacting with $\mathrm{K}$ protein 1 (ZIK1), was first described in 1996 by Denisenko et al. (38). In addition to the nine contiguous zinc fingers in the $\mathrm{C}$-terminus, ZIK1 contains a KRAB-A domain thought to be involved in transcriptional repression. ZIK1 demonstrated aberrant DNA methylation, it might function on tumor development (39). It was unknown whether there was a relationship between decreasing VEGI174 expression level and increasing MYC or ZIK1 expression levels in RCC tissues. There are many studies that have reported MYC and ZIK1 expression and function, thus we did not examine them with IHC.

Contrary to the decreasing expression level of VEGI174, three other factors increased in RCC tissues. The first, ACLY was an important enzyme involved in lipid biogenesis that is linked with glucose metabolism. Studies have shown a role for ACLY in tumorigenesis whereby increased levels of the enzyme leads to increased metabolic activity via activation of Akt signaling. Increasing lines of evidence suggest that enzymes involved in lipid biogenesis play a significant role in cancer cell proliferation and progression. In many cancer types such as glioblastoma, colorectal cancer, breast cancer, non-small cell lung cancer, hepatocellular carcinoma etc., the level of ACLY has been found to be quite high as compared to normal cells (40-43). In this study, mRNA levels of ACLY in RCC were higher than that in normal tissues. The IHC did not show the same result. Normal renal and RCC tissues all had positive staining. However, in RCC tissues, the staining was seen in all areas of the cell, including cell membrane, cytoplasm and nucleus. In normal renal tissues, ACLY was only seen in the cytoplasmic area of renal tubular epithelia cells. We could not explain this kind of difference.

Secondly, ENO1 generates ATP during glycolysis. Several studies have shown that ENO1 is a multifunctional protein participating in several physiological processes, including growth control, hypoxia tolerance and autoimmune activities $(44,45)$. Remarkably, accumulating evidence have suggested that ENO1 can function as an oncogenic protein by promoting cell proliferation, invasion and metastasis. ENO1 expression is frequently increased in diverse tumors, including head and neck, thyroid, breast, lung, prostate, colon and gastric cancer, glioma and cholangio carcinoma (46-49). Moreover, overexpression of ENO1 is positively associated with progression and poor prognosis in several tumors (49). Up to now, the role of ENO1 in RCC remains unknown. In this study, ENO1 expression was higher in RCC than that in normal renal according to the results of RNAseq and IHC. However, contrary to other tumors, the ENO1 expression level in the low stage and grade group was higher than that in the high stage and grade group.

Thirdly, AKR1C3 was originally cloned from human liver and prostate cDNA libraries $(50,51)$. It is a monomeric cytoplasmic protein of 323 amino acids and a molecular weight of $37 \mathrm{kDa}(52,53)$. AKR1C3 is overexpressed in numerous cancers, including cancers of the prostate, breast, uterine, blood, lung, brain and kidney, whereas its upregulation frequently correlates with tumor invasiveness and aggressiveness (54-61). In this study, mRNA level of AKR1C3 in RCC was higher than that in normal tissues. Moreover, the higher expression level of AKR1C3 was positively correlated with higher RCC stage and grade. This is contrary to the reduction of VEGI174 in higher RCC stage and grade. IHC results also suggested this kind of correlation. So, AKR1C3 may correlate with the progression of RCC.

In conclusion, in this study, five proteins were found to interact with VEGI174. It is still unclear whether VEGI174 acts in collaboration with other binding proteins in form of a protein complex. In contrast to the decrease in VEGI174 expression in RCC tissues, the expression of the above five proteins was increased in RCC tissues. Based on other studies, overexpression of the above five proteins is associated with progression in several tumors. The exact function of those five proteins is unknown in RCC. We did not know the relationships between VEGI174 and above five proteins too. However, the results indicated that VEGI174 has more functions than we now know in the supression of the development and progression of RCC. Therefore, further studies should be performed to clarify this matter. Moreover, the expression of AKR1C3 was correlated with high-grade and high-stage RCC. It is suggested that AKR1C3 not only interacts with VEGI174, but also closely relates with the progression of RCC.

\section{Conflicts of Interest}

The Authors declare no potential conflicts of interest.

\section{Acknowledgements}

This study was supported by the National Natural Science Foundation of China, grant No. 81372138 and Cancer Research Wales (W.G.J.). 


\section{References}

1 Tan KB, Harrop J, Reddy M, Young P, Terrett J, Emery J, Moore $\mathrm{G}$ and Truneh A: Characterization of a novel TNF-like ligand and recently described TNF ligand and TNF receptor superfamily genes and their constitutive and inducible expression in hematopoietic and non-hematopoietic cells. Gene 204: 35-46, 1997.

2 Zhai Y, Yu J, Iruela-Arispe L, Huang WQ, Wang Z, Hayes AJ, Lu J, Jiang G, Rojas L, Lippman ME, Ni J, Yu GL and Li LY: Inhibition of angiogenesis and breast cancer xenograft tumor growth by VEGI, a novel cytokine of the TNF superfamily. Int J Cancer 82: 131-136, 1999.

3 Zhai Y, Ni J, Jiang GW, Lu J, Xing L, Lincoln C, Carter KC, Janat F, Kozak D, Xu S, Rojas L, Aggarwal BB, Ruben S, Li LY, Gentz $\mathrm{R}$ and Yu GL: VEGI, a novel cytokine of the tumor necrosis factor family, is an angiogenesis inhibitor that suppresses the growth of colon carcinomas in vivo. Faseb J 13: 181-189, 1999.

4 Yao JJ, Zhang M, Miao XH, Zhao P, Zhu SY, Ding H and Qi ZT: Isoform of vascular endothelial cell growth inhibitor (VEGI72-251) increases interleukin-2 production by activation of T lymphocytes. Acta Biochim Biophys Sin (Shanghai) 38: 249-253, 2006.

5 Jin T, Guo F, Kim S, Howard A and Zhang YZ: X-ray crystal structure of TNF ligand family member TL1A at 2.1A. Biochem Biophys Res Commun 364: 1-6, 2007.

6 Chew LJ, Pan H, Yu J, Tian S, Huang WQ, Zhang JY, Pang S and Li LY: A novel secreted splice variant of vascular endothelial cell growth inhibitor. Faseb J 16: 742-744, 2002.

7 Parr C, Gan CH, Watkins G and Jiang WG: Reduced vascular endothelial growth inhibitor (VEGI) expression is associated with poor prognosis in breast cancer patients. Angiogenesis 9: 73-81, 2006.

8 Yue TL, Ni J, Romanic AM, Gu JL, Keller P, Wang C, Kumar S, Yu GL, Hart TK, Wang X, Xia Z, DeWolf WJ and Feuerstein GZ: TL1, a novel tumor necrosis factor-like cytokine, induces apoptosis in endothelial cells. Involvement of activation of stress protein kinases (stress-activated protein kinase and p38 mitogenactivated protein kinase) and caspase-3-like protease. J Biol Chem 274: 1479-1486, 1999.

9 Haridas V, Shrivastava A, Su J, Yu GL, Ni J, Liu D, Chen SF, Ni Y, Ruben SM, Gentz R and Aggarwal BB: VEGI, a new member of the TNF family activates nuclear factor-kappa B and c-Jun N-terminal kinase and modulates cell growth. Oncogene 18: 6496-6504, 1999.

10 Xiao Q, Hsu CY, Chen H, Ma X, Xu J and Lee JM: Characterization of cis-regulatory elements of the vascular endothelial growth inhibitor gene promoter. Biochem J 388: 913920, 2005.

11 Hou W, Medynski D, Wu S, Lin X and Li LY: VEGI-192, a new isoform of TNFSF15, specifically eliminates tumor vascular endothelial cells and suppresses tumor growth. Clin Cancer Res 11: 5595-5602, 2005.

12 Jia W, Sander AJ, Jia G, Ni M, Liu X, Lu R and Jiang WG: Vascular endothelial growth inhibitor (VEGI) is an independent indicator for invasion in human pituitary adenomas. Anticancer Res 33: 3815-3822, 2013.

13 Zhang N, Sanders AJ, Ye L, Kynaston HG and Jiang WG: Expression of vascular endothelial growth inhibitor (VEGI) in human urothelial cancer of the bladder and its effects on the adhesion and migration of bladder cancer cells in vitro. Anticancer Res 30: 87-95, 2010.
14 Zhang N, Sanders AJ, Ye L, Kynaston HG and Jiang WG: Vascular endothelial growth inhibitor, expression in human prostate cancer tissue and the impact on adhesion and migration of prostate cancer cells in vitro. Int J Oncol 35: 1473-1480, 2009.

15 Wu L, Li X, Ye L, Shayiremu D, Deng X, Zhang X, Jiang W, Yang Y, Gong K and Zhang N: Vascular endothelial growth inhibitor 174 is a negative regulator of aggressiveness and microvascular density in human clear cell renal cell carcinoma. Anticancer Res 34: 715-722, 2014.

16 Zhang N, Wu P, Wu L, Shayiremu D, Shan H, Ye L, Jiang WG, Gong $\mathrm{K}$ and Yang $\mathrm{Y}$ : The differential expression of vascular endothelial growth inhibitor isoforms, VEGI251, VEGI174 and VEGI192 in human clear-cell renal cell carcinoma. Cancer Genom Proteom 10: 47-53, 2013.

17 Zhang N, Wu P, Shayiremu D, Wu L, Shan H, Ye L, Zhao X, Cai J, Jiang WG, Gong K and Yang Y: Suppression of renal cell carcinoma growth in vivo by forced expression of vascular endothelial growth inhibitor. Int J Oncol 42: 16641673, 2013.

18 Prehn JL, Thomas LS, Landers CJ, Yu QT, Michelsen KS and Targan SR: The $\mathrm{T}$ cell costimulator TL1A is induced by FcgammaR signaling in human monocytes and dendritic cells. $\mathrm{J}$ Immunol 178: 4033-4038, 2007.

19 Turro E, Su SY, Goncalves A, Coin LJ, Richardson S and Lewin A: Haplotype and isoform specific expression estimation using multi-mapping RNA-seq reads. Genome Biol 12: R13, 2011.

20 Ljungberg B, Campbell SC, Choi HY, Jacqmin D, Lee JE, Weikert S and Kiemeney LA: The epidemiology of renal cell carcinoma. Eur Urol 60: 615-621, 2011.

21 Sidana A and Srinivasan R: Therapeutic Strategies for Hereditary Kidney Cancer. Curr Oncol Rep 18: 50, 2016.

22 Samplaski MK, Zhou M, Lane BR, Herts B and Campbell SC: Renal mass sampling: an enlightened perspective. Int J Urol 18: 5-19, 2011.

23 Choueiri M, Tannir N and Jonasch E: Adjuvant and neoadjuvant therapy in renal cell carcinoma. Curr Clin Pharmacol 6: 144-150, 2011.

24 Powles T, Staehler M, Ljungberg B, Bensalah K, Canfield SE, Dabestani S, Giles R, Hofmann F, Hora M, Kuczyk MA, Lam T, Marconi L, Merseburger AS, Volpe A and Bex A: Updated EAU Guidelines for Clear Cell Renal Cancer Patients Who Fail VEGF Targeted Therapy. Eur Urol 69: 4-6, 2016.

25 Zhang N, Sanders AJ, Ye L and Jiang WG: Vascular endothelial growth inhibitor in human cancer (Review). Int J Mol Med 24: 3-8, 2009.

26 Park SS, Lillehoj HS, Hong YH and Lee SH: Functional characterization of tumor necrosis factor superfamily 15 (TNFSF15) induced by lipopolysaccharides and Eimeria infection. Dev Comp Immunol 31: 934-944, 2007.

27 Bamias G, Mishina M, Nyce M, Ross WG, Kollias G, RiveraNieves J, Pizarro TT and Cominelli F: Role of TL1A and its receptor DR3 in two models of chronic murine ileitis. Proc Natl Acad Sci USA 103: 8441-8446, 2006.

28 Cassatella MA, Pereira-da-Silva G, Tinazzi I, Facchetti F, Scapini P, Calzetti F, Tamassia N, Wei P, Nardelli B, Roschke V, Vecchi A, Mantovani A, Bambara LM, Edwards SW and Carletto A: Soluble TNF-like cytokine (TL1A) production by immune complexes stimulated monocytes in rheumatoid arthritis. J Immunol 178: 7325-7333, 2007. 
29 Yang CR, Hsieh SL, Teng CM, Ho FM, Su WL and Lin WW: Soluble decoy receptor 3 induces angiogenesis by neutralization of TL1A, a cytokine belonging to tumor necrosis factor superfamily and exhibiting angiostatic action. Cancer Res 64: 1122-1129, 2004.

30 Felsher DW and Bishop JM: Reversible tumorigenesis by MYC in hematopoietic lineages. Mol Cell 4: 199-207, 1999.

31 Felsher DW and Bishop JM: Transient excess of MYC activity can elicit genomic instability and tumorigenesis. Proc Natl Acad Sci USA 96: 3940-3944, 1999.

32 Jain M, Arvanitis C, Chu K, Dewey W, Leonhardt E, Trinh M, Sundberg CD, Bishop JM and Felsher DW: Sustained loss of a neoplastic phenotype by brief inactivation of MYC. Science 297: 102-104, 2002.

33 Arvanitis C and Felsher DW: Conditionally MYC: insights from novel transgenic models. Cancer Lett 226: 95-99, 2005.

34 Dang CV: c-Myc target genes involved in cell growth, apoptosis, and metabolism. Mol Cell Biol 19: 1-11, 1999.

35 Giuriato S, Ryeom S, Fan AC, Bachireddy P, Lynch RC, Rioth MJ, van Riggelen J, Kopelman AM, Passegue E, Tang F, Folkman J and Felsher DW: Sustained regression of tumors upon MYC inactivation requires p53 or thrombospondin-1 to reverse the angiogenic switch. Proc Natl Acad Sci USA 103: 1626616271, 2006.

36 Rakhra K, Bachireddy P, Zabuawala T, Zeiser R, Xu L, Kopelman A, Fan AC, Yang Q, Braunstein L, Crosby E, Ryeom $\mathrm{S}$ and Felsher DW: CD4(+) T cells contribute to the remodeling of the microenvironment required for sustained tumor regression upon oncogene inactivation. Cancer Cell 18: 485-498, 2010.

37 Shroff EH, Eberlin LS, Dang VM, Gouw AM, Gabay M, Adam SJ, Bellovin DI, Tran PT, Philbrick WM, Garcia-Ocana A, Casey SC, Li Y, Dang CV, Zare RN and Felsher DW: MYC oncogene overexpression drives renal cell carcinoma in a mouse model through glutamine metabolism. Proc Natl Acad Sci USA 112: 6539-6544, 2015.

38 Denisenko ON, O’Neill B, Ostrowski J, Van Seuningen I and Bomsztyk K: Zik1, a transcriptional repressor that interacts with the heterogeneous nuclear ribonucleoprotein particle $\mathrm{K}$ protein. J Biol Chem 271: 27701-27706, 1996.

39 Mihara M, Yoshida Y, Tsukamoto T, Inada K, Nakanishi Y, Yagi $\mathrm{Y}$, Imai $\mathrm{K}$, Sugimura $\mathrm{T}$, Tatematsu $\mathrm{M}$ and Ushijima $\mathrm{T}$ : Methylation of multiple genes in gastric glands with intestinal metaplasia: A disorder with polyclonal origins. Am J Pathol 169: 1643-1651, 2006.

40 Khwairakpam AD, Shyamananda MS, Sailo BL, Rathnakaram SR, Padmavathi G, Kotoky J and Kunnumakkara AB: ATP citrate lyase (ACLY): a promising target for cancer prevention and treatment. Curr Drug Targets 16: 156-163, 2015.

$41 \mathrm{Zu} \mathrm{XY,} \mathrm{Zhang} \mathrm{QH,} \mathrm{Liu} \mathrm{JH,} \mathrm{Cao} \mathrm{RX,} \mathrm{Zhong} \mathrm{J,} \mathrm{Yi} \mathrm{GH,} \mathrm{Quan} \mathrm{ZH}$ and Pizzorno G: ATP citrate lyase inhibitors as novel cancer therapeutic agents. Recent Pat Anticancer Drug Discov 7: 154$167,2012$.

42 Migita T, Narita T, Nomura K, Miyagi E, Inazuka F, Matsuura M, Ushijima M, Mashima T, Seimiya H, Satoh Y, Okumura S, Nakagawa $\mathrm{K}$ and Ishikawa Y: ATP citrate lyase: activation and therapeutic implications in non-small cell lung cancer. Cancer Res 68: 8547-8554, 2008.

43 Migita T, Okabe S, Ikeda K, Igarashi S, Sugawara S, Tomida A, Taguchi R, Soga T and Seimiya H: Inhibition of ATP citrate lyase induces an anticancer effect via reactive oxygen species:
AMPK as a predictive biomarker for therapeutic impact. Am J Pathol 182: 1800-1810, 2013.

44 Kang HJ, Jung SK, Kim SJ and Chung SJ: Structure of human alpha-enolase (hENO1), a multifunctional glycolytic enzyme. Acta Crystallogr D Biol Crystallogr 64: 651-657, 2008.

45 Migneco G, Whitaker-Menezes D, Chiavarina B, Castello-Cros R, Pavlides S, Pestell RG, Fatatis A, Flomenberg N, Tsirigos A, Howell A, Martinez-Outschoorn UE, Sotgia F and Lisanti MP: Glycolytic cancer associated fibroblasts promote breast cancer tumor growth, without a measurable increase in angiogenesis: evidence for stromal-epithelial metabolic coupling. Cell Cycle 9: 2412-2422, 2010.

46 Tu SH, Chang CC, Chen CS, Tam KW, Wang YJ, Lee CH, Lin HW, Cheng TC, Huang CS, Chu JS, Shih NY, Chen LC, Leu SJ, $\mathrm{Ho} \mathrm{YS}$ and $\mathrm{Wu} \mathrm{CH}$ : Increased expression of enolase alpha in human breast cancer confers tamoxifen resistance in human breast cancer cells. Breast Cancer Res Treat 121: 539-553, 2010.

47 Tsai ST, Chien IH, Shen WH, Kuo YZ, Jin YT, Wong TY, Hsiao JR, Wang HP, Shih NY and Wu LW: ENO1, a potential prognostic head and neck cancer marker, promotes transformation partly via chemokine CCL20 induction. Eur J Cancer 46: 1712-1723, 2010.

48 Kashat L, So AK, Masui O, Wang XS, Cao J, Meng X, Macmillan C, Ailles LE, Siu KW, Ralhan R and Walfish PG: Secretome-based identification and characterization of potential biomarkers in thyroid cancer. J Proteome Res 9: 5757-5769, 2010.

49 Pernemalm M, De Petris L, Branca RM, Forshed J, Kanter L, Soria JC, Girard P, Validire P, Pawitan Y, van den Oord J, Lazar V, Pahlman S, Lewensohn R and Lehtio J: Quantitative proteomics profiling of primary lung adenocarcinoma tumors reveals functional perturbations in tumor metabolism. J Proteome Res 12: 3934-3943, 2013.

50 Khanna M, Qin KN, Wang RW and Cheng KC: Substrate specificity, gene structure, and tissue-specific distribution of multiple human 3 alpha-hydroxysteroid dehydrogenases. J Biol Chem 270: 20162-20168, 1995.

51 Lin HK, Jez JM, Schlegel BP, Peehl DM, Pachter JA and Penning TM: Expression and characterization of recombinant type 23 alpha-hydroxysteroid dehydrogenase (HSD) from human prostate: demonstration of bifunctional 3 alpha/17 betaHSD activity and cellular distribution. Mol Endocrinol 11: 19711984, 1997.

52 Lin HK, Steckelbroeck S, Fung KM, Jones AN and Penning TM: Characterization of a monoclonal antibody for human aldo-keto reductase AKR1C3 (type 23 alpha-hydroxysteroid dehydrogenase/ type 5 17beta-hydroxysteroid dehydrogenase); immunohistochemical detection in breast and prostate. Steroids 69: 795-801, 2004.

53 Fung KM, Samara EN, Wong C, Metwalli A, Krlin R, Bane B, Liu CZ, Yang JT, Pitha JV, Culkin DJ, Kropp BP, Penning TM and Lin HK: Increased expression of type 2 3alphahydroxysteroid dehydrogenase/type 5 17beta-hydroxysteroid dehydrogenase (AKR1C3) and its relationship with androgen receptor in prostate carcinoma. Endocr Relat Cancer 13: 169$180,2006$.

54 Nakamura Y, Suzuki T, Nakabayashi M, Endoh M, Sakamoto K, Mikami Y, Moriya T, Ito A, Takahashi S, Yamada S, Arai Y and Sasano H: In situ androgen producing enzymes in human prostate cancer. Endocr Relat Cancer 12: 101-107, 2005. 
55 Jansson AK, Gunnarsson C, Cohen M, Sivik T and Stal O: 17betahydroxysteroid dehydrogenase 14 affects estradiol levels in breast cancer cells and is a prognostic marker in estrogen receptorpositive breast cancer. Cancer Res 66: 11471-11477, 2006.

56 Jin J, Krishack PA and Cao D: Role of aldo-keto reductases in development of prostate and breast cancer. Front Biosci 11: 2767-2773, 2006

57 Mahadevan D, DiMento J, Croce KD, Riley C, George B, Fuchs D, Mathews T, Wilson C and Lobell M: Transcriptosome and serum cytokine profiling of an atypical case of myelodysplastic syndrome with progression to acute myelogenous leukemia. Am J Hematol 81: 779-786, 2006.

58 Azzarello JT, Lin HK, Gherezghiher A, Zakharov V, Yu Z, Kropp BP, Culkin DJ, Penning TM and Fung KM: Expression of AKR1C3 in renal cell carcinoma, papillary urothelial carcinoma, and Wilms' tumor. Int J Clin Exp Pathol 3: 147$155,2009$.
59 Birtwistle J, Hayden RE, Khanim FL, Green RM, Pearce C, Davies NJ, Wake N, Schrewe H, Ride JP, Chipman JK and Bunce CM: The aldo-keto reductase AKR1C3 contributes to 7,12-dimethylbenz(a)anthracene-3,4-dihydrodiol mediated oxidative DNA damage in myeloid cells: implications for leukemogenesis. Mutat Res 662: 67-74, 2009.

60 Penning TM and Byrns MC: Steroid hormone transforming aldoketo reductases and cancer. Ann N Y Acad Sci 1155: 33-42, 2009.

61 Suzuki T, Miki Y, Moriya T, Akahira J, Hirakawa H, Ohuchi N and Sasano H: In situ production of sex steroids in human breast carcinoma. Med Mol Morphol 40: 121-127, 2007.

Received May 22, 2017

Revised June 8, 2017

Accepted June 9, 2017 